\title{
A Strategic Analysis of Enhancing the Economic Extroversion Level of $X i$ 'an from the Belt and Road Perspective
}

\author{
Min LU1a*, Ya-fei GUO ${ }^{2 b}$ \\ 1Shaanxi Institute of International Tread \& Commerce, Xi'an ,China \\ 2Shaanxi Environmental Monitoring Central Station, Xi'an ,China \\ a271267664@qq.com, b86148708@qq.com
}

Keywords: The Belt and Road, Economic extroversion, Strategy.

\begin{abstract}
At present, our country economy enters the new normal, the strategy of the Belt And Road is not only beneficial to promote trade between the countries and regions along the interaction, more conducive to promoting the transformation of the pattern of economic development in our country. As the new starting point of the Silk Road Economic Belt, Xi 'an should seize the opportunity, actively participate in exchanges and cooperation in the Middle East, strengthen the foreign trade development, improve extroverted level. This article mainly analyzes the relationship between the strategy of The Belt and Road and the promotion of xi 'an extroverted level, and further put forward the strategies of enhancing the economic extroversion level of xi 'an.
\end{abstract}

\section{一带一路视域下提升西安经济外向度的策略分析}

\author{
路敏 ${ }^{1, a *}$ 郭亚飞 ${ }^{2, b}$ \\ ${ }^{1}$ 陕西国际商贸学院, 西安, 中国 \\ 2 陕西省环境监测中心站, 西安, 中国 \\ a271267664@qq.com,b86148708@qq.com
}

关键词: 一带一路; 经济外向度; 策略

摘要：当前, 我国经济进入新常态, “一带一路” 战略的实施不仅有利于促进沿线国家与地区 间的贸易互动, 更有利于促进我国经济发展方式的转型。西安作为丝绸之路经济带的新起点, 应该抓住这个发展机遇, 积极参与中亚地区交流合作, 加强对外贸易发展, 提升经济外向度。 本文主要分析了 “一带一路” 战略与提升西安经济外向度的关系, 并进一步提出提升西安经 济外向度的策略。

\section{1. 引言}

近年来, 在国际贸易环境复杂多变、全国外贸总体形势严峻的情况下, 西安市外贸逆势增 长, 保持良好的发展势头。据西安海关统计, 2015 年, 西安市进出口总值 252.6 亿美元, 比 上年增长 15\%, 同期全国进出口总值下降 7\%, 实际利用外资突破 40 亿美元, 服务外包合同额 14.9 亿美元, 分别是 2010 年的 2.6、3.5 和 5.1 倍。虽然西安市对外贸易进出口总额、经济 外向度、实际利用外资情况纵向对比发展迅速。然而, 与全国以及其他同等内陆城市相比还 存在进出口贸易总额处于落后、经济外向度偏低、利用外资的能力较差的问题, 严重影响了 西安市经济外向度的发展 ${ }^{[1]}$ 。 


\section{2. “一带一路” 战略与提升西安经济外向度的关系}

2013 年 9 月和 10 月, 习近平总书记在访问中亚四国时提出建设 “丝绸之路经济带” 和 “21 世纪海上丝绸之路” 的战略构想 (简称 “一带一路”), 得到国内外各界的高度关注。学术界 普遍认为 “一带一路” 战略不仅有利于解决国内区域发展的不平衡, 更有利于我国形成全方 位开放的新格局。为推进 “一带一路” 战略的全面建设, 我国将充分发挥国内各地区比较优 势, 实行更加积极主动的开放战略, 加强东中西互动合作, 全面提升开放型经济水平。在古 代, 西安曾长时期作为东西商贸文化通道丝绸之路的东方磁极 ${ }^{[1]}$, 在现代又成为国家规划的 内陆型国际化大都市, 并承担着 “欧亚经济论坛” 永久会址的光荣使命。因而, 西安凭借其 区位的战略性，文化的根基性，产业的高端性，科教的前沿性，交通信息的枢纽性，生态环 境的厚载性, 与西部省份及中亚各国相比具有明显的比较优势, 理应也完全有条件成为向西 开放的第一引擎 ${ }^{[2]}$ 。可见，从提升西安经济外向度的角度讨论 “一带一路” 战略的实施, 对 于西安国际化大都市建设, 对于丝绸之路的复兴, 对于丝绸之路经济带的建设, 对于推动亚 洲大陆腹地 (中国西部一中亚) 的再次崛起, 进而实现中华民族的复兴梦具有重要理论和实践 意义。

\section{3. 提升西安经济外向度的策略}

\section{1 发展国际旅游相关配套服务}

旅游业是西安市的招牌产业，通过发展旅游业来提高西安市的经济外向度是现阶段切实 可行的方法。通过对西安市国际旅游的数据分析, 发现西安市国际旅游的产值增长缓慢, 与 其他通等城市相比, 西安市的 $4 \mathrm{~A}$ 以及 $5 \mathrm{~A}$ 级景点数最多, 但是西安市的星级宾馆数目不及其 他城市，住宿餐饮业在社会消费中的比重也不及其他同等城市，在大力发展旅游业的同时， 发展住宿餐饮业、批发零售业、交通运输业, 适应国际游客的需求, 打造良好的旅游环境, 发挥西安市的自然历史优势，从国际旅游方面，提升西安市的经济外向度。

3.1 .1 优化旅游业投资，打造世界级旅游目的地。提高旅游服务业的服务水平，优化旅 游环境, 以此提高国际旅游的发展, 吸引更多外国游客; 在以后的旅游业发展投资中，可侧 重于住宿和餐饮方面的投资，引进国外高档酒店和知名餐饮，以外商投资的形式发展酒店餐 饮业; 另外，提高国际旅游服务业，提高国际导游综合素质、提高国际旅游景点服务等。

3.1 .2 旅游要与文化、教育相结合，形成 “旅游-文化-教育大平台”。通过将西安市得天 独厚的自然历史条件与文化产业、学校人文教育基地相结合, 提升旅游的文化价值和教育价 值。在历史文化旅游基础上, 大力发展大学的文教旅游、城市中心综合文化旅游、生态观光 旅游等; 其次, 可以将旅游服务嵌入到西安的国际国内政治经济文化活动、学术交流会议、 各行业年会等交流项目中, 发展文化旅游; 另外, 大力营造西安市古丝绸之路起点城市以及 汉唐古都的文化氛围，提升旅游特色。

3.1 .3 发展 “互联网+旅游” 模式。通过网络宣传、网络自助游、虚拟景区等方式发展西 安古城历史文化旅游。同时，在线上做好餐饮、住宿、交通、旅游、购物和娱乐六个方面的 全面协调发展，做好 “六方面，一站式” 服务，极大方便游客的出行问题，同时促进西安市 其他经济消费的发展。

3.1.4 发展旅游产业集群。旅游业是西安市经济发展的重要推动力, 发展旅游集群, 极 大程度地提高旅游业的发展水平。政府要做好协调和服务工作，依靠市场进行职能定位，创 造集群条件和环境, 提供公共服务; 旅游中介和旅游企业做好游客服务, 大力发展新型旅游 方式，与政府和游客之间形成联动机制。同时，旅游企业和中介之间做好信息共享和协同发 展，建立旅游信息平台和互动网络，实现区域内市场信息共享。

\section{2 优化招商引资策略}

通过招商引资可以带动周边产业的发展和完善，对优化产业结构、提升经济总量、发展 
外向型经济都有着重要的影响。由于西安市的城市发展水平、产业结构等因素的制约, 致使 西安市的外商投资环境并没有太多的吸引力。因此想要吸引外商投资, 提高外资利用程度, 需要拓展多种招商引资策略。通过投资结构的调整、投资模式的创新以及投资政策的优化, 结合 “一带一路” 的战略目标，制定具吸引力的投资策略，吸引跨国企业的入住以及外商投 资者的注资, 以此来拉动西安市的经济增长以及产业结构的调整和升级, 并进一步创建对外 开放的新模式。具体策略如下:

3.2 .1 调整外商投资结构。分析国际市场未来的需求和发展趋势，并进行积极引导，调 整西安市外商投资结构。在当前的经济发展中, 发展制造业是提高经济发展的重要方式, 在 后期的外商投资中, 要以加大制造业的投资为重点, 加大高新技术行业的投资为新的突破点。 针对 “一带一路” 经济带的发展, 以及各国的市场需求, 调整本土行业发展的侧重点, 并且 要与欧洲以及中亚等国家形成优势互补，扩大对外开放与合作。

3.2 .2 创建外商投资模式。外商投资结构的调整, 主要根据西安市产业发展规划为向导, 以制造业和高新技术产业发展为基础, 吸引特定类型的外商投资。在制造业方面, 主要以外 商投资设备和技术为主, 进行科学招商, 举办招商专题活动, 例如对美国的能源化工、德国 的装备制造等进行招商洽谈，大力发展西安市的航空产业优势，以外商投资的形式，提升航 空装备制造业的发展; 针对高新技术产业的发展，在招商引资的同时要与西安市的高校科研 院所进行结合，形成 “外商技术资金支持、高校科研院所参与、吸收内化为手段、技术和应 用创新为目的”, 将国外的技术进行引进一消化一吸收一应用一再创新, 同时加强本土产业的培 育和发展。

3.2.3 改善外商投资政策。利用国家西部大开发战略中的相关政策，制定有西安市特色 的吸引外商投资策略，充分发挥西安市的文化、历史、旅游、高校科研院所等方面的优势。 制定分段式投资策略，优惠政策要分年限分时间段，根据投资期限的不同，相应的优惠措施 也不同。以政策引导外商投资，对高新技术产业、科技研究行业、教育医疗服务行业、管理 咨询业等行业的外商投资要与时俱进，从利用产业长期发展为目的，制定相应的投资政策。

\section{3 发展铁路航空运输业}

通过对西安、重庆以及武汉等城市的交通运输网络的分析，西安市的铁路和航空运输发 展相对落后, 国际航线相对较少, 通过发展铁路和航空运输, 特别是发展国际货运, 提高铁 路和航空运输效率, 以此来发展西安市国际旅游和对外贸易, 从而提高西安市的经济外向度。

通过对西安市以及其他城市交通运输年度数据以及国际货运专列数据的汇总分析，发现 西安市的交通运输主要以公路为主, 说明西安市的交通发展水平相对落后, 在当前社会, 铁 路和航空运输已经成为世界物流发展的主导力量, 西安市应该大力发展铁路运输和航空运输, 提高国际贸易、国内物流、产品进出口的竞争力, 提高出口贸易运输的便利程度。具体可以 从以下几个方面进行发展。

3. 3. 1 提高铁路运输服务水平。西安市作为西北地区的枢纽城市, 铁路运输相对发达, 但是铁路货运量与其他通等城市相比, 相对偏小, 只有通过大力发展铁路运输, 提高铁路运 输的服务水平, 特别是准点率, 科学调度分配集装箱, 发展铁路货运, 特别是国际货运。随 着 “长安号” 的开通, 西安市出口货物通过 “长安号” 直达中亚和欧洲地区, 促进西安市外 贸进出口的发展。

3. 3.2 发展航空运输优势。西安市作为航空产业发展的重要城市, 在航空运输业的发展 上具有独特的优势。通过国际合作以及紧紧抓住国家战略发展, 大力发展航空运输, 与国外 航空公司开通国际航线, 建立合作协议。另外, 加强对优势产业的聚集, 发展临空产业, 建 立空港发展经济区, 以高端产业和知识型产业为主, 具备研发、商务、服务等功能, 形成特 色鲜明的航空运输产业。

3. 3.3 建立物流运输新模式。通过建立 “物流-金融一贸易” 融合扩散发展模式, 形成 “一 带一路” 经济带发展中的物流集散地。通过国际货运物流产业发展, 发展贸易加工产业, 发 展物流中转站功能, 在中转同时, 承包货物的包装、半加工等, 形成物流与加工贸易相结合 
的发展模式，与此同时，发展国际金融，对物流和加工贸易提供保险、融资等服务，保证物 流加工贸易的发展。

3.3.4 提高国际货运专列运输水平。提高国际货运服务水平和服务质量, 采用国际先进 的物流管理方式方法，从物流体制、管理模式、物流规划、盈利模式等方面对其进行优化调 整，将西安打造成为 “一带一路” 经济带上的物流中心。通过 “国家外交政策为主、地方政 府协助为辅、企业对外合作为依托、外贸出口为根本” 的发展模式, 进行更广泛的国际合作， 提高国际货运专列的发车次数。通过与其他城市的合作, 建立西安物流中转中心, 为其他城 市的货物出口提供运输服务，以此来提高国际货运专列的运输效率。

综上所述，发展国际旅游、优化招商引资策略、着力发展铁路航空运输这三个方面作为 突破点, 是当前西安市经济和产业发展环境下, 能够又快又好发展西安市外向型经济的最佳 路径。国际旅游的发展重点从旅游服务业以及高档住宿餐饮业的发展投资为主; 优化招商引 资策略, 要以国际市场需求为导向, 以吸引长期投资为目标, 推动本土企业发展为根本; 铁 路航空运输的发展要以开通更多国际航线为手段, 提高国际货运专列运输水平和铁路服务业 为基本，以此来提升西安市外向型经济发展水平，是当前最有效的途径。

\section{致谢}

本文为陕西省教育厅项目《开创丝绸之路经济带与陕西对外贸易战略的结构性调整》 (15JK2012)与西安社科基金自筹项目《一带一路战略下提升西安对外贸易发展水平的策略研 究》(16Z18)的阶段性成果之一。

\section{References}

[1] Min LU, Jing-ni DAI, Chao LI, Lin-zhen WEI. An Analysis Report on Xi'an Foreign Trade Environment from the Perspective of Constructing "Silk Road Economic Belt" [J]Journal of Changchun Normal University.2014(10):85-88.

[2] Li-ming LI. Revive the Silk Road [J] West China Development, 2013, 07:113-114. 